\title{
A FACTUAL ANALYSIS OF CERTAIN PROPOSED AMENDMENTS TO THE NEGOTIABLE INSTRUMENTS LAW
}

\author{
ROSCOE B. TURNER
}

The first objective in amending the Negotiable Instruments Law should be to bring the statute into as nice adjustment with present needs as possible. This consideration, it is believed, overshadows all others. The act, viewed as a part of the contract of the several parties to negotiable paper, should be written to permit them to carry their transactions through efficiently and in the manner contemplated. At the same time, the legislation should not cloak unfair practices. It should be drafted to require only a minimum of recourse to the courts. Although these ends seem obvious, there is by no means agreement as to how the statute should be amended to attain them. What is a fair rule, what is an efficient or convenient one, or, in fact, what is the understanding of the parties to commercial paper concerning their agreement in any given case?

An endeavor is made in the following pages to produce something more substantial than mere conjecture on these points with reference to certain of the more debatable of the changes which may be made in the statute. ${ }^{2}$ In December a questionnaire was sent out by the writer to some two hundred and fifty banls, trust companies, bond and investment houses, one hundred and fifty lawyers and to the teachers in Association schools giving the negotiable instruments course-a' matter all told of about four hundred questionnaires. Replies were received from all sections of the country. Both the large city bank and the country bank viewpoint is represented. So also, country and city attorneys were interrogated, questionnaires being sent in each state to those listed as handling a commercial practice. In a large percentage of cases, judged from the care with which replies were amplified as well as from direct statements to that effect and the time taken in giving a reply, it was evident that pains had been taken to give a considered answer. Each questionnaire was

I A technical analysis of the proposed amendments was made in an earlier article. The writer emphasized the importance of ascertaining the fict basis for the proposed changes as being of probably greater importance today than a careful adherence to common-law doctrine. See Turner, Rcvision of the Negotiable Instruments Law (1928) 3S YALE L. J. 25. 
signed by the individual answering, or in the case of banks, by an officer of the institution.

Before proceeding to an analysis of the replies received, however, recognition must be given to the position sometimes taken that such findings have little, if any, place in a legal discussion. Certainly courts, possibly in part for administrative reasons, have been distinctly averse to giving any weight, at least in their opinions, to such considerations. The majority of the Supreme Court recently in a question peculiarly one of factwhether a state statute was within the "police power" or constituted a taking of property "without due process of law"preferred rather to place their decision largely on supposed principles derived from other cases involving other facts, than to give weight to a comprehensive marshalling of facts concerning the need for the particular statute. ${ }^{2}$

Granting that principles are extremely useful as generalizations from prior cases, should these be pursued to their logical end in the interest of symmetry, leaving it to an already overburdened legislature to clear up the wreckage, or should the courts modify their principles to fit the distinctly new cases as they arise? The ideal of a fixed self-consistent body of principles from which the rule for the new case can be deduced has been slow to give ground. Yet it is clear that in every field the process of putting new wine into old bottles, of modifying this principle here and of refusing to apply that rule there, has been going on continually. It should be equally clear that the grounds for making these changes are often never stated. And while, no doubt, they have usually been well based in fact, the emphasis on the principle supposed to control the case, and on the prior decisions supposed to stand for that principle, has obscured the process by which it is determined that one result rather than another should be reached. ${ }^{3}$ It may be largely because of this that there has been developed no adequate method for consciously evaluating data on a disputed point, the real process involved in reaching a decision in close cases. ${ }^{4}$

\footnotetext{
2 Ribnik v. McBride, 277 U. S. 350, 48 Sup. Ct. 545 (1928). The caso related to the validity of a New Jersey statute regulating employment agencies. For an able discussion of the problem, see Comment (1928) 38 Yate L. J. 225. It has been this type of case more than any other in which an efrort has been made to support argument on prior cases and legal principles with facts indicating the practical bearing of a decision one way or the other, which after all should be, and possibly is, the chief consideration of the court. The briefs by Brandeis and Frankfurter in tho labor cases have become classics.

3 The writer wishes to acknowledge his indebtedness to Professor Waltor Wheeler Cook for several of the ideas expressed in this paragraph.

4 A carefully worked out scheme for collecting data on bank payments, weighting the various factors involved, appeared in this Journal recently.
} 
In fact, not only has no method been developed for analyzing facts having to do with a problem, but much information which it is believed would have been extremely valuable in many cases has either been assumed by the court as fact without evidence, or excluded altogether as irrelevant to the precise issue before the court. For example, to use a clear case, Chief Justice Gibson in McFailand. v. Newmans would undoubtedly have refused any evidence that the movement to subject a seller to warranties, instead of clogging commerce with law suits, was actually producing fewer suits by removing the grounds for such actions. The first fellow servant cases were decided on the theory, at least in part, that a rule of non-responsibility on the part of the master would be most likely to minimize the number of personal injury cases." Although this consideration had a place, and it is believed no factor was entitled to greater weight, there was almost no evidence taken on the point.

It must be conceded, however, that much of the reluctance on the part of courts to place reliance on so-called facts is perhaps natural enough. There are facts and facts. The expert witness has had a malodorous record. So-called statistics may be made to support either side of a case. And certainly court or legislature should not be asked to abandon its owm intelligence to decide with the majority adduced by a questionnaire. It is quite possible by careful phrasing of questions or inadequate presentation of the implications of a question to evoke answers of no value whatever. But the time-honored alternative of assuming facts without any evidence, and merely saying, often subconsciously, "for commercial reasons," or of resorting to that overworked dodge of deciding the new case "on principle" is altogethe: indefensible. Some effort must be made to bridge this gap. The findings on this questionnaire and the attempted evaluation of answers are offered merely as further data, not in any sense as final proof of the points made.

The proposed changes chosen for consideration were selected more or less at random, partly because the writer entertained somewhat different views concerning some of them than have usually been taken. They were further thought to be questions of such a character that the issue could be brought out with reasonable sharpness in few words-a necessity if the attention of busy individuals is to be expected and much more a necessity if an opinion on the point is to be of value. A brief paragraph setting forth the pros and cons of a non-legalistic charncter thought to be involved was used in each case with no indication

See Moore, An Institutional Approach to the Law of Commercial Banlsing (1929) 38 YaLE L. J. 703.

59 Watts 55 ( $\mathrm{Pa} .1839$ ).

6 Farvell v. Boston \& Worcester R. R., 4 Mietc. 49 (Miass. 1842). 
of the writer's opinion. To the extent only that this has been done successfully may the replies be regarded as valid.7

The issue involved in the first case presented by the questionnaire is simple enough: should a special indorsement on bearer paper control its future negotiation? The proposed amendment would change the rule which has uniformly prevailed in this country and in England for years-that paper drawn payable to bearer may still be negotiated by delivery notwithstanding it has been specially indorsed. The submission of the case ${ }^{8}$ stated carefully the probable implications of the change, not to constitute a "brief" on the question, but to make sure that the important aspects of the problem were understood. The questions asked were as follows:

(a) Should the proposed change apply to coupon bonds so that their payment and transfer would depend on the regularity of endorsements?

(b) If the proposed change were to be made, in your opinion would the fact that an item appeared on its face to be payable to bearer mislead people dealing with it into disregarding endorsements?

(c) Are holders generally better able to guard against losing bearer paper than purchasers or paying banks are to detect forged endorsements upon it?

(d) May holders insure against loss or theft of bearer paper to better advantage than purchasers or paying banks may against forged endorsements?

(e) In your judgment, balancing all interests, is the proposed change to be favored?

(f) Would you favor legislation, similar to that in England, validating good faith payments of demand order instruments by banks to their customers, even though the instrument bears a prior forged endorsement?

Since sending out the questionnaire it has seemed that possibly question (a) was unfair, although the proposed amendment would apply to bonds as well as to other instruments. It appears altogether unnecessary to inject the forged indorsement question into bond transfers and payments, often amounting to very large sums. A bond that has been outstanding say for thirty

in view of the importance of this aspect of the matter each submission will be set out hereafter in the footnotes.

s The following was the first case taken up by the questionnaire:

"It has been proposed that Section $40 \mathrm{~N}$. I. L. (uniform enumoration) be stricken out and that Section 9 (5) be amended so that bearer paper which has been specially endorsed may not subsequently be negotiated, as at present, by delivery alone. Further negotiation would be by endorsemont plus delivery. The amendment would appear to operate to the advantage of holders who have lost bearer paper so endorsed. It would probably operate to the disadvantage of bona fide purchasers, collecting banks and anyone paying such items, in that it would extend the forged endorsemont risks to all such paper." 
years might become so clogged with indorsements and guaranties as to be almost non-transferable. ${ }^{9}$ If the parties want protection of this sort they should buy registered bonds. It seems very doubtful, although no facts are available on the point, whether the saving to an occasional holder to accrue from the proposed change would at all compensate for the increased cost of handling which the amendment would necessitate. It is believed that to a perhaps lesser extent this applies also to other bearer paper.

The banks and bond houses answering question (a) were unanimous to the effect that the amendment should not apply to bonds or coupons. These opinions must be given considerable weight, inasmuch as banks are not only collecting and paying agents, but purchasers and holders of such securities as well. The lawyers were divided in their views, about seventy-five per cent opposing the proposed change. In contrast with this, the law teachers were unanimously in favor of the change, even as applied to bonds. ${ }^{10}$ The division of opinion in regard to bearer paper generally, raised by question (e), was substantially the same although one of the large New York banks thought the change defensible if limited to bearer checks. There was scarcely any support whatever, even among the banks, for the English rule sanctioning payments of demand instruments made over forged indorsements. ${ }^{11}$

The attitude of the banks with reference to the risk of transit loss in the case of bearer bonds was expressed by one of the principal Bridgeport banks, saying that "it is far better to use insurance as protection against loss when mailing" than to incumber payment and transfer as proposed. It was further brought out with regard to the risk of safekeeping that bonds are usually kept with a safe deposit company so that actually this risk is very small. Moreover, it is not at all clear that holders would ever specially indorse bonds or other bearer paper

9 When one considers also that several hundred thousand dollars of such bonds are not infrequently presented in a single day for payment at their maturity, something of the problem the ameniment would force on the maker or paying agent may be better appreciated.

10 This attitude was stated in one instance to be based on the fact that it was assumed to represent the commercial viewpoint. Possibly this is to be traced to the statement made by Professor Brannan in regard to bearer paper generally that "the opinion of bankers consulted by the writer and by his colleague, Professor Williston, was unanimous to this efrect." BrannaN, Negotiable Instrunients Law (4th ed. 1926) 327. It is interesting to compare the unanimous opinions to the opposite effect elicited by this questionnaire.

${ }^{11}$ It seems probable that the English rule in this connection [Briss of EXCHANGE ACT $\$ 60]$, which has been of considerable protection to paying banks, was not sufficiently understood. At the same time the negative answer by the banks is some testimony to the disinterestedness with which the questionnaire was answered. 
to obtain the protection of the proposed amendment in the large number of cases where the paper is being held merely as an investment. Special indorsements are not used until a transfer is to be made.

Questions (b), (c) and (d) applying to bearer paper generally were designed as in the nature of special interrogatories to test the validity of the above results. It was thought that a finding should be had on the possible unfairness of the change to those who might assume that bearer paper was still transferable by delivery. Further, assuming that losses will continue to occur through fault of neither party, an estimation was wanted of the relative ability of the parties to the transaction to avoid the loss in the first instance, or to shift it conveniently. ${ }^{12}$ An attorney in Ohio expressed himself on this endeavor in the strictly orthodox way: "Do not feel this question should enter into discussion of the law. Right and wrong should govern, not insurance."

The banks and attorneys answered (b) in the affirmative and practically all of the teachers conceded that the change might lead into error in some cases, at least at first. Of course, if an exception is to be made in the case of bonds, coupons and other similar bearer paper, as seems necessary, the position of bearer checks would always be more or less misleading. Only two answered flatly that it would not be misleading. The questions concerning ability to avoid loss, or to insure against it to advantage, also produced a sharp division of opinion. The banks were unanimous to the effect that a holder is in a better position ordinarily to guard his paper, or to insure it when sending it through the mail, than a purchaser, collecting bank or paying agent would be to detect forged indorsements. But whatever weight should be given to this consideration, the affirmative answer would seem quite obvious, when one considers that it is impossible to verify all indorsements before handling an item. Disregarding entirely the fact that the holder need not have taken a bearer instrument to start with, he can take any precautions for the protection of his paper he may think desirable. In this the lawyers also agreed. But the teachers again were largely on the opposite side.

Aside from bonds, the most important type of paper the amendment would affect would be bearer checks. These circulate to a considerable extent. In fact even order checks in large numbers are transferred by blank indorsement. It seems fair to say, though no facts are at hand to support the statement, that for the most part only items involving relatively small amounts in local circulation are handled in this way. Obviously as to these the statute would ordinarily not come into play in

12 These tests in their application both to court decisions and new legislation were discussed more fully in the writer's previous article, supra note 1. 
any case because it is not the habit to indorse specially. Thus the only risk of much importance in the situation, which is not in practice voluntarily assumed by the parties, would arise in the case of collections requiring transit by mail. As to this point, however, there already is authority that proper handling of bearer paper by collecting banks may require that they carry insurance. ${ }^{13}$ Blanket policies covering this risk can be carried by banks, in view of the volume handled, at relatively low cost.".s It would seem that a much better solution of the problem than that proposed would be to make provision in the proposed uniform bank collection statute for this point, leaving the rules as to the transfer and payment of bearer paper unchanged.

The second case, ${ }^{15}$ the proposal to amend Section 71 concerning the time for presentment of demand instruments, was accompanied by the following questions:

(a) Should an effort be made to bring about earlier retirement of all demand paper?

(b) Would the law be more readily understood if the reasonable-time-after-issue test were to apply both to drawers and endorsers?

(c) Have decisions of the courts as to what constitutes a reasoncble time in these cases been satisfactory in your experience?

(d) Is it commercially practicable to await court decision as to what amounts to a reasonable time, before you may know what your rights are against secondary parties?

(e) Would you favor legislation fixing definitely the time within which presentment of interest-bearing demand notes must be made as, for example, one year after date?

(f) If a time should be stated for presentment, what period should be fixed in the case of non-interest-bearing demand notes?

${ }^{13}$ See Bank of Monango v. Ellendale Nat. Banl, 52 N. D. 8, 201 N. W. 839 (1924), 40 L. R. A. 889 (1926). This case concerned a transmission of Liberty Bonds.

14 Safe-keeping accounts, according to a large New Yorls banl, are now quite generally covered by blanket policies and such insurance can likewise be obtained to cover transit losses.

15 The case was submitted as follows:

"It is proposed to amend Section" 71 relating to presentment for payment of demand instruments. The suggestion is to provide that, hereafter, presentment must be made (and of course followed by notice of dichonor) as to each endorser, within a reasonable time after his endorsement and, as to dravers of demand bills, within a reasonable time after the issue of the instrument. At present the reasonable-time-after-issue test applics to endorsers of demand notes, but presentment of demand bills may be made within a reasonable time after the last negotiation thereof, in order to charge endorsers and drawers. In Nebraska the statute has been modified to provide the reasonable-time-after-issue test for all drawers and endorsers of demand instruments. The proposed amendment would probably tend to force the earlier retirement of demand paper at peril of losing endorsers." 
It is evident that this case could not readily be presented to raise a sharp issue. It is difficult to show that it makes much difference whether a reasonable-time-after-indorsement test or a reasonable-time-after-issue test is to be applied. Both are somewhat illusory. The writer prefers the latter in the interest of simplicity of application, inasmuch as the same rule could be applied as to all secondary parties. Very few answers to questions (b), however, gave any support to the view that one test would be any simpler or better understood than the other.

The first question, whether an effort should be made to bring about the earlier payment of demand paper, was based on the assumption that the proposed reasonable-time-after-indorsement test, if adopted, would result in a somewhat shorter time than that which obtains with the reasonable-time-after-issue test. The banks replying to the question were about equally divided, a majority considering that there was no need to resort to this means of forcing the earlier retirement of such paper.10 A majority of both the lawyers and teachers held the opposite view.

Possibly this result must be qualified by the answers to questions (d), (e) and (f). In reply to (d) it was agreed by nearly everyone that it would be commercially desirable, if possible, to state a more definite rule than any "reasonable time" test. There was practically unanimous agreement, in answer to question $(\theta)$, that one year from date of issue would be a satisfactory period within which presentment should be made to charge indorsers on interest bearing demand notes. And while most answers fixed the same date for non-interest bearing instruments, a few suggested a shorter period, as thirty days or six months. It seems probable from this that no such urgency for early presentment of demand paper was felt as might appear from the answers to question (a). But while this evidence would support a fixed rule of one year, at least as applied to interest-bearing demand notes, the subject is one which should be given thorough consideration. Particularly is this true in the case of items arising in foreign commerce. But at least, it may be said that a change to increased definiteness would meet with much greater favor than the proposed amendment.

The third case ${ }^{17}$ lent itself more readily to brief presentation. What rights should a purchaser after maturity be given against an accommodation signer? The following questions were asked:

${ }^{16}$ A writer for one of the largest commercial paper houses in the country, who professed over thirty years experience in the field, answered question (a), "Why? I see no reason."

17 This question was presented as follows: 
(a) Do accommodation parties generally expect to limit their responsibility to cases where the accommodated party has negotiated the instrument before maturity?

(b) Do purchasers from the payee (accommodated party) after maturity assume that the accommodation party can be held responsible?

(c) Should the question be left for court decision as cases arise?

(d) As to demand notes, should a definite time, for example, one year after date, be stated within which negotiation must take place if the accommodation party is to be held?

(e) Should the same time apply in the case of demand bills of exchange drawn or accepted for accommodation?

A substantial majority both of banks and lawyers were of the opinion that accommodation signers do not expect to limit their responsibility to cases where negotiation is had before maturity. Is The teaching profession was almost unanimous to the opposite effect. It is possible that both sets of answers were motivated to some extent by what was regarded as being the better rule. One or two of the teachers amplified their replies to say that they did not like the case of Marling 2. . Jones. ${ }^{10}$ An attorney from Oklahoma, on the other hand, expressed the majority view to the contrary, answering question (a) "Absolutely No." It was agreed by a large majority of banks, lawyers and teachers in reply to question (c) that the rule adopted should be settled definitely one way or the other, and not left to the courts for a decision based on the supposed intentions of the parties in each case. So question (d), whether a one year time limit should be fixed for negotiation of demand notes, was approved by a large majority in each class. A few favored a shorter period for demand bills. No one wanted a longer period except a minority who felt that no limit should be imposed.s?

In view of these replies it would seem very difficult to say that

\footnotetext{
"In several states the courts recently have ruled that a good faith purchaser of an instrument first negotiated sometime after maturity might recover against the accommodation maker or endorser. The courts regarded this result as required by Section 29. It is proposed to amend the seetion so that recovery in these cases will depend on whether, in the opinion of a court or jury, the accommodation party may be said to have intended negotiation after maturity."

18 The Boston banks thought accommodation parties intended such a limitation, which, to that extent at least, verifies Professor Brannan's finding that "this is the merchant's view of the case" which he ascertained after "consultations with a number of bankers, who tere unanimous in their opinions." BraNNAN, op. cit. supra note 10, at 288 .

19138 Wis. 82,119 N. W. 981 (1909). This case has been followed recently, making the point one of practical importance if uniformity is to be attained. See (1926) 24 MIICH. L. REv. 847.

20 An attorney in South Dakota took this view, saying that a limitation "Would add a technical defense that (the) parties did not have in mind."
} 
there is any uniform "mercantile understanding" concerning the time within which negotiation of time paper should take place for this purpose. There is considerable opinion in favor of fixing the rule definitely. As to demand paper this can be attained by the one year provision which has been proposed. Possibly the best solution of the problem as to time paper, however, would be to state a presumption that the parties intended to be bound only in case negotiation occurred before maturity, leaving it open in those cases where the parties agreed otherwise for the converse to be proved without infringing upon the parol evidence rule.

Only one situation out of the many proposed amendments to Sections 119 and 120 was presented-that relating to the question whether suretyship defenses should be available to the accommodation maker. ${ }^{21}$ It is of course well settled that the accommodation party as indorser is accorded a type of suretyship position; at the same time a large majority of states have held that an accommodation party as maker or co-maker has contracted as a primary party and is not therefore entitled to such defenses. ${ }^{22}$ To the writer, the majority rule is much to be preferred inasmuch as it is more adaptable than the minority rule. An accommodation party can, by signing as a primary party, waive his suretyship defenses, while as an indorser he can preserve them. In whichever capacity he signs, his position is definite. This avoids all of the difficulties attendant upon proving whether in a particular case the holder had notice of the accommodation character of the signing or not. Notice of the accommodation character would be immaterial in either case, thus avoiding a fruitful source of litigation.

The following interrogatories were presented : ${ }^{23}$

(a) In your experience, do accommodation parties now - assume that in signing as maker or co-maker their obligation is greater than if they signed on the back of the paper. as endorser?

(b) If so, is this accounted for by the fact that, as

21 This subject was presented as follows:

"It is proposed to make a number of changes in Sections 119 and 120 relating to discharge of instrument and of parties with the general object of giving accommodation parties the benefits of common-law suretyship defenses. To consider one situation affected, suppose a stockholder signs a note with his company and for its accommodation. He may sign as (1) endorser, (2) co-maker, or (3) if the instrument is drawn to the order of the company, as sole maker. If the payee were subsequently to extend tho time of payment, for example, without obtaining the accommodation signer's consent, it is held in a majority of states that the accommodation party would be discharged in (1) but not in (2) and (3). The suggested change would probably allow the signer to be discharged in all three cases."

22 BRANNAN, op. cit. supra note 10, at 721.

23 See supra note 21 for a statement of the problem as presented. 
endorser, an accommodation signer is entitled to notice of dishonor, while, as maker or co-maker he is not?

(c) Is it convenient commercially to provide either of two possible contracts for the accommodation signer, depending on his bargain, as is done in most states; that is, if he signs as endorser, to accord him the protection of any signer in that capacity, but, if he signs as maker or co-maker, to provide that he assumes the obligation of a primary party and is not discharged, for example, because of an extension of time?

(d) Is there any injustice in denying suretyship defenses to the accommodation maker?

The first point to be verified was the importance commonly attached in the business world to the two signings-as indorser and as maker. It was thought that there was a geneial belief that an accommodation party assumes a more onerous obligation as maker than as indorser. Questions (a) and (b) were designed to ascertain whether this assumption had any basis in fact. Over three to one of the total replies indicated the existence of such a general understanding. A few doubted that accommodation parties generally had any understanding of their obligation, regardless of the position in which they signed. Question (b) probably called for too close a distinction to be answered with any degree of assuiance. Of those answering (a) affirmatively, however, the large majority answered (b) "in part" or "partially" or "perhaps to some extent," indicating that the matter of notice was not understood to be the whole distinction. Of course this general finding has considerable support also in the opinions of the majority courts in which it is said that the accommodation maker" in so signing assumes a "primary obligation." 24 Evidently this is more than a technical view.

The next question, (c), raised the principal issue squarely, although at least one bank answered in the negative because of the supposed indefiniteness of the situation under the majority rule. Needless to say it is more definite than the proposed amendment would be, if that involves going back to the suretyship rules at common-law, as apparently is proposed. The banlis by a substantial majority answered question (c) in the affirmative. Among the teachers the affirmative vote was greater, but the attorneys by a majority of three favored the contrary view that a "surety" is entitled to the usual suretyship defenses regardless of the capacity in which he signs. The answers to (d) concerning the possible injustice of the majority rule were colored largely by the view taken of the parties' understanding of the situation. The bankers who thought that accommodation parties now understand their obligations to be greater

24 See, for example, Union Trust Co. v. Mrcinty, 212 MIass. 205, 98 N. E. 679 (1912). 
as maker than as indorser answered that there was no injustice in denying such signers suretyship defenses. This amounted to saying that a signing as maker constituted a waiver of these defenses. Although this evidence, taken as a whole, cannot of course be regarded as at all conclusive, it certainly affords little support for the proposed amendment on the point. It would be better to change the rule in the minority states to accord with that generally obtaining.

Two situations were taken up which have not yet been made the subject of a proposed amendment. The first of these ${ }^{20}$ related to the highly uncertain question of what acceleration provisions may be employed in an instrument without destroying its negotiability. ${ }^{26}$ Is there a place for such clauses in negotiable paper and, if so, what, if any, limitations should be prescribed? The following questions were asked:

(a) Would you favor attempting to define certain contingencies having to do with the loan or its security which alone might be made events of default without destroying negotiability?

(b) Would you favor legislation similar to that in Wisconsin?

(c) In your opinion, would any extension of the use of acceleration provisions in negotiable instruments operate unfairly to borrowers?

(d) Would the increased security to lenders from such provisions be reflected in lower interest rates?

(e) Would such provisions affect adversely the transferability of paper containing them?

Questions (a) and (b) were framed to raise the problem whether a broad authorization should be given, as in Wisconsin, or whether only certain types of provisions should be sanctioned. The banks for the most part answered both in the affirmative, showing a lack of discrimination, but giving proof of the commercial importance of the subject. Several banks, one of them

25 In the questionnaire the matter was presented as follows:

"In many states a provision accelerating the maturity of a time instrument, for example, upon the borrower's failure to deposit additional collateral in event of depreciation in the market value of collateral alrendy pledged, would render the instrument non-negotiable. In Wisconsin tho statute has been modified so that without affecting its negotiability, an instrument may be drawn to provide for the acceleration of maturity upon the happening of any contingency. No amendment has been proposed as yet in this case."

26 The effect of the current type of acceleration provisions has only recently come before the Court of Appeals in New York and then only in an indirect way. It seems probable, however, that the New York court when called upon to do so will go to considerable lengths to sanction the provisions of this character in ordinary use. Most of the authorities are cited in First Nat. Bank v. Blackman, 249 N. Y. 322, 164 N. E. 113 (1928). 
a leading Boston bank, however, approved question (a) but refused to sanction (b) for the reason that it was "too broad." Almost all the teachers were also of this opinion. A considerable number of lawyers were interested in the administrative difficulties that might be encountered in applying any limiting description. Their attitude seemed to be that, granted the desirability of such clauses, the type and extent of their use should be left largely to the good judgment of the people concerned. This would have the merit of permitting change to meet varying conditions without requiring further amendment to the statute. It does not appear that the Wisconsin amendment has resulted in misuse.

Questions (c), (d) and (e), designed to test the general desirability of acceleration provisions, were answered in the same way by a large majority of each class. It was pointed out in answer to (e) that an acceleration note may be considerably less uncertain and less harsh on the borrower than a demand note, which, it appears, is coming to be used more often in many sections as an alternative form. ${ }^{27}$ It was interesting to note the reaction to the question whether interest rates might be lowered to reflect the greater security given the holder of a note containing acceleration provisions. Of the few who did not answer with a fint negative, the answers ranged from that of an Illinois banl, "Some cases, yes" through "doubtful," "perhaps," "very doubtful" to "possibly." Practically everyone was agreed that, if the law were definite, not requiring recourse to the courts for continual interpretation, the introduction of such clauses would tend to facilitate transfer rather than the reverse. This, no doubt, was based on the assumption, although the point was not adverted to, that a purchaser, without notice of an earlier acceleration, might be a holder in due course, contrary to the decisions in some states. ${ }^{28}$ Whether it is desirable to go to the extent of the Wisconsin act or not, there seems to be little doubt from the evidence received in this connection that the time has come to sanction further acceleration provisions. In the opinion of the writer it will be difficult to devise any formula meeting the requirements of the case which would be as satisfactory as the Wisconsin amendment.

The second question presented ${ }^{20}$ which has not as yet been

${ }^{27} \mathrm{~A}$ St. Louis bank submitted a form it employs which reads: "On demand, and if no demand is made, then on ..." From the malser's standpoint this differs little from the ordinary demand note, as far as certainty of time is concerned.

${ }^{28}$ See Hodge v. Wallace, 129 Wis. 84, 108 N. W. 212 (1906). The point should be provided for by amendment.

29 The questionnaire presentation follows:

"It was held recently in New York that the refusal of a banl to certify a check upon proper presentment did not constitute a dishonor allowing the 
made the subject of an amendment related to the effect to be given to a refusal by a bank to certify a properly presented check. The following interrogatories were used:

(a) Do holders understand that a refusal to certify is not a dishonor?

(b) In approximately what percentage of cases, if any, do banks refuse certification of checks which they would be willing to pay?

(c) What reasons, if any, exist for refusing certification of such items?

(d) In what cases, if any, do banks certify checks which they would not pay?

(e) Should a bank be held responsible to its depositor for injury to his credit if it refuses to certify a check which it would pay?

The answers to question (a) established rather clearly that most people now assume that a refusal to certify constitutes a dishonor, as would a refusal to pay. In view of this, a rule requiring a re-presentment for payment, in case of a refusal to certify, before recourse may be had against secondary parties seems to be an insistence on formality having little justification. ${ }^{30}$

The answers to question (b), however, indicate that the problem is not so easily settled. In most states it appears banks certify almost any check which they would pay-the only excep. tion being the very small check where the service would not warrant the additional bookkeeping required. But in several states a practice is developing of refusing to certify checks altogether, or only at the instance of the drawer. ${ }^{31}$ The most widely stated reason for this development is the Illinois decision ${ }^{32}$ which held a bank obligated to pay a check according

holder immediate recourse against the drawer. The same rule apparently applies to endorsers. It is thus made necessary for a holder to re-present such an item for payment in order to charge secondary parties."

${ }^{30} \mathrm{~A}$ holder was recently denied a cause of action on this statement of facts in New York. Wachtel v. Rosen, 223 App. Div. 416, 228 N. Y. Supp. 476 (1st Dep't 1928), aff'd, 249 N. Y. 386, 164 N. E. 326 (1928).

${ }^{31} \mathrm{~A}$ bank in Decatur, Illinois stated that its practice is to certify only at the request of the drawer in order to avoid possible double liability in case a raised check is certified. See National City Bank v. Nat. Bank of the Republic, 300 Ill. 103, 132 N. E. 832 (1921). A New Jersey attornoy wrote that the same practice prevails among some banks in New Jersoy. An attorney in Reno, Nevada wrote to the same effect. A Kansas City bank stated that, inasmuch as the Missouri courts have held that a drawor who has procured certification may stop payment, it refuses all certifications. See Bathgate v. Exchange Bank, 199 Mo. App. 583, 205 S. W. 875 (1918). A bank in Helena, Montana wrote, "We always pay rather than certify," giving as a reason, "too much trouble." A reply from Florida indicates that another reason may be that when a cashier's check is issued in lieu of certification a charge may be made for the service.

${ }^{32}$ National City Bank v. Nat. Bank of the Republic, supra note 31. 
to its tenor at the time of certification where the payee's name had been altered, although recognizing that the bank was not privileged to charge the payment to its customer's account. At the time this case was decided, it was both criticized and approved for theoretical reasons, ${ }^{33}$ but whatever the merits of that controversy, it would seem highly essential that now the question be resolved contrary to the Illinois decision, for certainly no one would wish to jeopardize the entire certification practice in order to protect the bona fide holder in the rare instances where the item was certified after having been raised. Although business would, of course, continue even though the certification practice were to be abandoned entirely, it would seem desirable to encourage rather than discourage the use of bank certifications." The liquidation of business payments in a higher type of paper makes for greater confidence and stability in commercial dealings. An amendment to Section 62 should be proposed making it clear that both certifications and acceptances apply only to the original tenor of the instrument.

With this out of the way there would seem to be little reason left for the position of the New York court in holding that a refusal to certify should not constitute a dishonor. At the same time the question whether a bank should be liable to its customer for such refusal raises entirely different considerations. A large majority of all answers to question (e), perhaps naturally enough in the case of the banks, opposed such a result. A few banks, however, even in this case stated that the bank should be held responsible. With the possible exception of relatively small checks, there is much point in favor of adding this sanction in furtherance of the use of certifications. The point, however, is not one germane to the Negotiable Instruments Law.

In conclusion, it is recognized that the several factors considered important by the writer in connection with these questions may be valued differently by others. Whatever their weight and the validity of the findings upon them, they are at least relevant to the present inquiry. In time a process of evaluating such material more accurately may be worked out. Courts have

${ }^{33}$ See Brannan, op. cit. supra note 10, at 571 for citations of the discussions on both sides of this question.

s4 Concerning the certification practice in New York one of the large banks there wrote as follows: "In order to understand the practical considerations involved in your sixth question, it is necessary to lnow something of the volume of certifications which banks in large cities are now called upon to handle. In one of our offices alene during the period of active stock market operations, we have been called upon to certify in connection with brokerage transactions an average of at least twelve hundred checks a day, most of these during the hour between two and three o'clock P. MI. This is exclusive of the certifications for other customers of the office." 
never had such information available. ${ }^{35}$ It is probable that, in time, the consideration given to such material will be as serious as that given to the purely technical aspects of legal problems, ${ }^{30}$ which seem to have monopolized attention heretofore. There should be franker recognition of the fact that matters of legal theology, while extremely important, are by no means the sole questions involved in deciding a close case or in amending a statute where the decisions are in conflict.

The results of this investigation, while in no sense offered as conclusive proof, furnish a basis, at least, for questioning very seriously the desirability of certain of the proposed amendments. In particular, it seems quite doubtful whether any amendment should be sponsored as to bearer paper. In the case of the accommodation maker, the rule denying suretyship defenses, developed by a majority of the courts, would appear to have considerably greater support than the proposed return to the common-law doctrine. There is a pronounced tendency to favor a definite time within which negotiation must take place, both for purposes of charging secondary parties and for obligating the accommodation maker. Further provision should be made for acceleration clauses. And a fairly strong case seems to have been made for amending the statute to avoid the certification difficulties raised by the Illinois court.

${ }^{35}$ The procedure investigation being conducted this year by Professor Clark of the Yale Law School has already been of considerable assistance to the Connecticut Judicial Council.

${ }_{36}$ The sterility of the idea of fixed legal principles as a basis for decision in new cases is very nicely illustrated in the joint bank deposit situation, where parties and bank want to provide for survivorship. Courts whon confronted with the problem have employed all of their common-law categories, trust, gift, joint tenancy, tenancy by the entireties, contract for the benefit of third parties, testamentary disposition, agency and what not, in an effort to decide the question "according to law." Some have reached the conclusion that there should be survivorship, and many the reverso. While doctrine is of course important, it seems fairly clear that it should not be allowed to get in the way of an admittedly just result. The cases are discussed in Cleveland Trust Co. v. Scobie, 114 Ohio St. 241, 151 N. E. 373 (1926); noted in (1926) 36 YaLE L. J. 138. 